\title{
Makna Syifa dalam al-Qur'an (Analisis Semiotika Roland Barthes pada QS al-Isra 82)
}

\author{
The Meaning of Shifa in the Qur'an (Roland Barthes'Semiotics Analysis on QS al-Isra 82)
}

\section{Roma Wijaya}

Universitas Islam Negeri Sunan Kalijaga, Yogyakarta, Indonesia. 凶arrum0030@gmail.com
Article history:

Submitted: 11 July 2021

Accepted: 14 December 2021

Published: 24 December 2021

\begin{abstract}
This paper examines the meaning of shifa in the Qur'an as stated in Surah al-Isra [17]: 82 which can be used as a means of treating various diseases, both psychological and physical. Employing the semiotic theory of Roland Barthes consisting of two stages (the linguistic system which is also interpreted as denotative meaning and the system of mythology (myth) as connotative meaning), the results obtained that shifa is not only oriented to the psychic alone, but to healing both the psychic (spiritual) and physical. The message contained in the verse is that it is recommended to do treatment using the Qur'an, with lawful (halal) practices, and it is not allowed to practice medical treatment that can classify to shirk such as using magic spells, mediation of belief in objects, sacred places of worship, and other things that are superstitious.
\end{abstract}

Keywords: al-Qur'an; linguistic system; mythological system; Roland Barthes; semiotic analysis; shifa.

Abstrak: Tulisan ini mengkaji tentang makna syifa dalam Al-Qur'an sebagaimana tertuang dalam QS al-Isra [17]: 82 yang dapat digunakan sebagai sarana pengobatan berbagai penyakit, baik psikis maupun fisik. Dengan menggunakan teori semiotika Roland Barthes yang terdiri dari dua tahap (sistem linguistik yang juga diartikan sebagai makna denotatif dan sistem mitologi (mitos) sebagai makna konotatif), diperoleh hasil bahwa syifa tidak hanya berorientasi pada psikis saja, tetapi untuk penyembuhan baik psikis (spiritual) maupun fisik. Pesan yang terkandung dalam ayat tersebut adalah dianjurkan untuk melakukan pengobatan dengan menggunakan Al-Qur'an, dengan praktik yang halal dan tidak diperbolehkan melakukan praktik pengobatan yang dapat digolongkan ke dalam syirik seperti menggunakan mantra sihir, perantaraan benda-benda, tempat-tempat ibadah yang keramat, dan hal-hal lain yang bersifat takhayul.

Kata kunci: al-Qur'an; analisis semiotika; Roland Barthes; sistem linguistik; sistem mitologi; syifa. 


\section{Pendahuluan}

Kemukjizatan al-Quran dalam realitas kehidupan menunjukkan eksistensi dan siginifikansinya terhadap berbagai praktik manusia. Salah satunya adalah mengamalkan al-Qur'an sebagai media penyembuhan dan terapi berbagai macam penyakit. Salah satu konsep mediasi penyembuhan yang termaktub al-Qur'an adalah kata asy-Syifa. Konsep Syifa secara umum dipahami melalui kacamata teologis sebagaimana penafsiran-penafsiran yang telah ada. Makna syifa yang dikemukakan oleh Ibnu Qayyim sebagai pesoalan hidup yaitu penyembuhan kejiwaan dari gangguan-gangguan psikis. Dalam penafsirannya beliau banyak menguraikan penyembuhan penyakit melalui metode al-Qur'an dan sunnah. Ibnu Qayyim menyerap ayat-ayat al-Qur'an dan Hadits sebagai dalil dalam mengemukakan metode penyembuhan berbagai penyakit kejiwaan serta disebutkan faktor-faktor yang menyebabkan timbulnya penyakit. Kemudian, pandangan M. Quraish Shihab, al-Quran bukan hanya kitab hukum, al-Qur'an mengandung visi moral luar biasa yang bahkan melampaui zaman. Salah satunya adalah mengandung perihal syifa (penawar/pengobatan) yang mana ketika kita mendengarkan al-Qur'an dapat menghidupkan kembali hati, menstabilkannya, menghilangkan ketegangan dan kekacauan yang ada pada detak jantung. ${ }^{1}$

Penelitian tentang konsep syifa yang telah dikaji dapat diklasifikasikan menjadi tiga bentuk, yaitu: pertama, syifa dilihat dari dinamika tafsir. ${ }^{2}$ Kajian ini berfokus kepada pemahaman para penafsir terhadap term syifa dalam al-Qur'an. Kedua, syifa dipahami sebagai obat fisik. ${ }^{3}$ Konsep yang dimunculkan pada penelitian tersebut adalah syifa dapat dijadikan sebagai media pengobatan fisik. Ketiga, syifa dipandang sebagai obat rohani. ${ }^{4}$ Kajian ini mengklaim bahwa syifa merupakan mediasi pengobatan kejiwaan rohani manusia yang di dalam hatinya terdapat penyakit. Dari berbagai penelitian tersebut, kajian terhadap konsep syifa dengan analisis semiotika dari Roland Barthes tidak ditemukan. Oleh karena itu, kecenderungan penelitian ini adalah mengungkap aspek linguistik semiologis Roland Barthes terkait kata syifa dalam al-Qur'an.

Wacana konsep syifa dalam al-Qur'an berorientasi terhadap fenomena fisiologis, spiritual, dan sosiologis. ${ }^{5}$ Perbincangan konsep ini tidak lepas dari tiga hal tersebut, karena ketika melihat realitas teks dan konteks diperlihatkan diskusi jasmani dan rohani. Ditambah dengan penjelasan para ulama yang tidak berselisih tentang praktik al-Qur'an digunakan untuk penyembuhan bagi penyakit ruhani atau kejiwaan. Namun demikian, sebagaimana telah dijelaskan terdapat

${ }^{1}$ Abduldaem Kaheel, Al-Qur'an The Healing Book, II (Jakarta: Tarbawi Press, 2011), 5.

${ }^{2}$ Gista Naruliya Siswanti, "Eksistensi Dan Konsep Syifa' Dalam Tafsir Fakhrudin Al-Razi," Al-Mada: Jurnal Agama, Sosial, Dan Budaya 2, no. 2 (2019): 1-16, https://doi.org/10.31538/almada.v2i2.330; Ahmad Sofyan, "Konsep Syifa Perspektif Tafsir Sya'rowi" (Institut Perguruan Tinggi Ilmu Al-Qur'an Jakarta, 2016); Cucun Fuji Lestari, "Penafsiran Ayat-Ayat Syifa Dalam Al-Qur'an (Studi Komparatif Tafsir Al-Jailâni Dan Al-Assâs)" (Institut Ilmu Al-Qur'an Jakarta, 2019).

3 Aida Hidayah and Fitriana Firdausi, 'Redefining The Meaning of Asy-Syifa' In The Qur'an As Qur'anic Healing In Pshysical Ailments," Jurnal Studi Ilmu-Ilmu Al-Qur'an Dan Hadis 22, no. 1 (2021): 255, https://doi.org/10.14421/qh.2021.2201-12; Mohamed Akhiruddin Ibrahim, M Shahir Mohd Shah, and Rabiatul Adawiyah Mohd, "Concept of Shifa in Al-Quran: Quranic Medicine Approach in Healing Physical Ailment," AlQanatir International Journal of Islamic Studies. 1, no. 2 (2015): 1-19; Muhammad Hanif Shiwani, "A Thematic Analysis of Human Nutrition as Described in the Holy Qur' an," Journal of The British Islamic Medical Association 6, no. 2 (2020): 1-14.

${ }^{4}$ Muchlish M Hanafi, “Qur'anic Immunity,” in Webinar Prospek Dan Tantangan Al-Qur'an Sebagai Obat Di Masa Pandemi (Salatiga: IAIN Salatiga, 2020); Umar Latif, “Al-Qur'an Sebagai Sumber Rahmat Dan Obat Penawar (Syifa') Bagi Manusia,” Jurnal Al-Bayan 21, no. 30 (2014): 88, https://doi.org/10.22373/albayan.v20i30.125.

${ }^{5}$ Gista Naruliya Siswanti, “Eksistensi Dan Konsep Syifa’ Dalam Tafsir Fakhrudin Al-Razi," Al-Mada: Jurnal Agama, Sosial, Dan Budaya 2, no. 2 (2019): 2, https://doi.org/10.31538/almada.v2i2.330. 
perselisihan terhadap praktik al-Qur'an bagi penyakit fisik. ${ }^{6}$ Perihal syifa bahwa Allah Yang Maha Tinggi menurunkan dari Al-Qur'an apa yang orang-orang percaya sebagai "kesembuhan, ketenteraman dan rahmat bagi jiwa mereka dan menyelamatkan mereka dari kebingungan dan kerumitan, dan ini berbeda dengan para penindas yang semakin keras kepala karena dari kejahatan lipatan yang mereka bangun, dan dengan demikian meningkatkan kerugian". ${ }^{7}$

Oleh karena itu, pembahasan yang disajikan dalam tulisan ini sangat relevan dengan persoalan kehidupan masyarakat. Peneliti mencoba menelusuri makna syifa, yang disebut sebagai obat penyakit yang terkandung dalam al-Qur'an, dengan menggunakan analisis Roland Barthes melalui penelusuran pada sistem linguistik (denotasi) dan mitologi (konotasi).

\section{Mengenal Semiotika Roland Barthes}

Sebelum mengetahui semiotika Roland Barthes, lebih dulu diuraikan biografi singkatnya. Roland Barthes lahir dalam keluarga Protestan kelas menengah di Cherbourg, Prancis pada 12 November 1915. Ayahnya adalah seorang marinir yang meninggal dalam tugas saat masa kecil Barthes. Masa kecilnya dihabiskan di Bayonne, dan pada usia sembilan tahun ia pindah ke Paris bersama ibunya, yang bekerja sebagai penjilid buku. Perkembangan selanjutnya adalah pada tahun 1934 Barthes ingin masuk ke Ecole Normale Superiure. Namun, karena menderita TBC, obsesi itu berhenti. Selama menjalani perawatan di berbagai fasilitas medis, seperti sanatorium di Pyrenees dan Alps, ia memperbanyak tulisannya, termasuk mempelajari tentang eksistensialisme Marx dan Sartre. ${ }^{8}$

Rekam jejak pendidikan Barthes dalam mendalami kajian bahasa, dimulai dengan masuk ke Universitas Sorbone megambil kajian bahasa dan satra Perancis dan kajian klasik (Latin, Romawi, dan Yunani). Dia pun mengembangkan keahlian teater dan drama klasik bersama temannya. Kemudian Barthes menjadi seorang sastrawan dan dosen Prancis Prancis di Bucharest, Rumania, dan Kairo. Dirinya dikenal sebagai pemikir strukturalis yang sangat menggalakkan praktik model linguistik dan semiologi Ferdinand De Saussure. ${ }^{9}$ Adapun beberapa karya Barthes adalah Le degree Zero de I'ecriture (1953), Micheletpar Lui Meme (1954), Mythologies (1957), Sur Racine (1963), Elements de Semiologie (1964), Critique et Verite (1966), Systeme de la Mode (1967), S/Z (1970), The Death of Author (1968), The Pleasure of The Text (1975), Semiology and the Urban (1971), La Lumiere du Sud-Outest in Oncidents (1977), dan lain sebagainya. ${ }^{10}$ Barthes wafat pada tanggal 26 Maret tahun 1980 dalam sebuah kecelakaan lalu lintas. ${ }^{11}$

\footnotetext{
${ }^{6}$ Hidayah and Firdausi, 'Redefining The Meaning of Asy-Syifa' In The Qur'an As Qur'anic Healing In Pshysical Ailments."

${ }^{7}$ Muhammad Izzat Darwazah, Tafsirul Hadits: Tartibulas Suwar Hasb An-Nuzuli, II (Beirut: Darul Ghorbi Al-Islami, 2000), 423.

${ }^{8}$ Abdul Fatah, "Analisis Semiotika Roland Barthes Tentang Ashabul Fil,” AL-TADABBUR 5, no. 2 (2020): 236.

${ }^{9}$ Putu Krisdiana Nara Kusuma and Iis Kurnia Nurhayati, “Analisis Semiotika Barthes Pada Ritual Otonan Di Bali,” Jurnal Manajemen Komunikasi 1, no. 2 (2019): 201, https://doi.org/10.24198/jmk.v1i2.10519.

${ }^{10}$ James S Duncan and Duncan G Nancy, "Ideology and Bliss: Roland Barthes and The Secret Histories of Landscape," in Postmodernism: Critical Concepts, ed. Victor E. Taylor and Charles E. Winquist (London: Routledge, 1998), 65-66.

${ }^{11}$ Azkiya Khitmatiar, “Konsep Poligami Dalam Al-Qur'an (Aplikasi Semiologi Roland Barthes),” QOF 3, no. 1 (2019): 57, https://doi.org/10.30762/qof.v3i1.903.
} 
Semiotika adalah warisan pemikiran Barthes yang paling terkemuka. Secara etimologi, kata ini merujuk ke bahasa Yunani yaitu same yang memiliki arti penafsir tanda atau kata semeion yang artinya tanda (sign). ${ }^{12}$ Kemudian, secara terminologi sebagaimana definisi yang diberikan Barthes bahwa semiologi adalah ilmu tentang bentuk, karena mempelajari makna selain dari isinya. ${ }^{13}$ Semiotika dapat dipahami sebagai ilmu tentang tanda-tanda yang terdapat 3 unsur yaitu tanda, penanda, dan petanda. Tanda ini mengandung dua aspek, yaitu penanda (signifie, signifiant) adalah bentuk riil tanda itu, dalam bahasa berupa satuan bunyi, atau huruf yang terkandung sastra tulisan dan petanda (signified) adalah maknanya, yakni apa yang ditandai oleh penandanya. ${ }^{14}$

Roland Barthes memiliki pemikiran yang lebih luas. Hal ini dapat ditunjukkan dengan tidak berhentinya hanya kepada pemahaman kasat mata saja. Akan tetapi, melacak arti dari simbol atau simbol yang ada. Intisari dari pemikiran Barthes adalah pengembangan makna dari denotasi, konotasi, dan sampai kepada mitos. ${ }^{15}$ Barthes mengidentifikasikan semiologi kepada dua tahapan. Tahapan linguistik merupakan proses pencarian makna denotasi dan konotasi yang terdiri dari unsur tanda I (sign), penanda I (signifier), dan petanda II (signified). Setelah mengetahui makna denotasi dan konotasi, langkah selanjutnya adalah tahapan mitologi yang dapat menemukan sistem mitologi atau dikenal sebagai mitos. ${ }^{16}$ Berikut gambaran model semiotika Barthes sebagaimana dalam Bagan 1.

Linguistik
Mitos $\left\{\begin{array}{|r|r|}\hline \text { 1. Signifier (Penanda I) } & \text { 2. Signified (Petanda I) } \\ \hline \text { 3. Sign (Tanda I) } & \text { b. Petanda II } \\ \text { a. Penanda II } & \multicolumn{2}{c}{\text { Tanda II }} \\ \hline \multicolumn{3}{|c|}{} \\ \hline\end{array}\right.$

Bagan 1. Skema Semiotika Roland Barthes

Dengan demikian dapat dipahami bahwa semiotik Roland Barthes tidak berhenti pada kajian linguistik atau makna denotasi dan konotasi sebagaimana yang diungkapkan Ferdinand De Saussure atau dikenal juga tahapan pertama. Melainkan berkembang lebih dinamis, dengan

12 Dewi Umaroh, "Makna 'Abasa Nabi Muhammad Dalam Al-Qur'an (Aplikasi Semiotika Roland Barthes Terhadap QS 'Abasa [80]: 1)," Al-Bayan: Jurnal Studi Ilmu Al- Qur'an Dan Tafsir 5, no. 2 (2020): 118, https://doi.org/https://doi.org/10.15575/al-bayan.v5i2.11640.

${ }^{13}$ Roland Barthes, Mythologies (New York: The Noonday Press, 1991), 110.

${ }^{14}$ Rachmat Djoko Pradopo, "Semiotika: Teori, Metode, Dan Penerapannya Dalam Pemaknaan Sastra," Jurnal Humaniora 11, no. 1 (1999): 76, https://doi.org/10.22146/jh.628.

15 Definisi Denotasi adalah ungkapan yang jelas dan nyata seperti bola itu bulat, bunyi suara Singa itu mengaung, dan sebagainya. Konotasi adalah makna/ekspresi yang tersembunyi di balik simbol yang berada dibalik dari sesuatu, seperti ekspresi wajah, implementasi warna sebagai identitas, dan sebagainya.. Sedangkan mitos memiliki perkembangan makna yang muncul dalam publik masyarakat akibat dari pemaknaan masyarakat sendiri terhadap scope hubungan apa yang tampak (ekstensi) dan tanda-tanda apa yang tersirat dalam sesuatu (intensi). Lihat dalam tulisan RAGD Ismujihastuti and Adi Bayu Mahadian, "Representasi Wanita Dalam Sampul Album Raisa (Analisis Semiotik Roland Barthes Terhadap Sampul Album Raisa Andriana 'Raisa' Dan 'Heart to Heart')," $\begin{array}{llll}\text { EProceedings } \quad \text { Management, } & \text { 2015, }\end{array}$ https://openlibrarypublications.telkomuniversity.ac.id/index.php/management/article/view/3444.

${ }^{16}$ Fahrudin Fahrudin, "Tanah Sebagai Bahan Penciptaan Manusia: Analisis Semiologi Roland Barthes Pada Kata Thin Dalam Al-Qur'an," TAFSE: Journal of Qur'anic Studies 6, no. 1 (2021): 24, https://doi.org/10.22373/tafse.v6i1.8036. 
melakukan interpretasi makna denotasi dan konotasi berdasarkan konteks di mana tanda tersebut dihidupkan. ${ }^{17}$ Setelah melakukan interpretasi tersebut, maka kita akan melihat mitos yang berkembang di masyarakat pada saat itu. Sebuah mitologi mengubah nilai-nilai suatu budaya, pada kasus Borjuis, misalnya, Barthes menilai bahwa budaya Perancis tersebut berubah menjadi nilai universal dan alami. Hal itu mengubah budaya menjadi alami yang masih diakui statusnya sebagai mitos, dengan hasil produk budaya. ${ }^{18}$

Menurut pandangan penulis, semiotika Barthes bertujuan untuk menelisik ideologi ataupun makna-makna yang diciptakan oleh produser, istilah ini diungkapkan Barthes. Kemudian mengungkapkan bahwa tidak adanya kesesuaian antara mitos dengan fakta atau kenyataannya. Contoh tentang mainan anak-anak yang memiliki makna mitos bahwa anak kecil yang bervariasi memiliki makna yang bersanding kepada pola kehidupan kaum dewasa modern seperti mainan berbentuk tentara, miniatur alat kedokteran, transportasi, dan lain-lain. Mainan Prancis secara kasat mata memunculkan fungsi dunia orang dewasa yang mendorong anak kecil untuk mempersiapkan tantangan atau statusnya di masa mendatang, seperi mainan tentara yang bersiap menjadi tentara dan begitu seterusnya. ${ }^{19}$

\section{Analisis Semiotika Roland Barthes pada Ayat Syifa dalam al-Qur'an}

\section{Ayat-ayat tentang Syifa}

Derivasi kata syifa dalam al-Qur'an seluruhnya disebutkan sebanyak delapan kali yaitu: QS AtTaubat:14 dan 109, QS Asy-Syu'ara:80, QSYunus:57, QS An-Nahl:69, QS Al-Isra:82, dan QS Fushilat:44, 'Ali 'Imron:103. ${ }^{20}$ Kata Syifa dalam semua surat mengandung makna detoksifikasi, pengobatan dan penyembuhan segala penyakit tubuh dan pikiran yang dialami manusia. AlQur'an juga berfungsi sebagai penenang hati (penyembuh hati) yang dapat memberikan ketentraman pada pembacanya. Petunjuk Al-Qur'an mengenai syifa dengan berbagai bentuk pengungkapan dan berbagai bentuknya disebutkan sebanyak delapan kali penyebutan dengan berbagai varian katanya dalam Al-Qur'an. ${ }^{21}$

\section{Sistem Linguistik}

Pada sistem linguistik, tahap pertama adalah menelusuri makna kata syifa dari pandangan denotasinya yang akan dipahami maknanya sebagaimana Barthes menyebutnya dengan makna tingkat pertama. Sistem linguistik ini juga dikenal sebagai pembacaan secara tekstual khususnya terhadap QS al-Isra: 82. Adapun yang menjadi fokus kajian adalah QS al-Isra : 82, berikut adalah teksnya:

${ }^{17}$ Umaroh, "Makna 'Abasa Nabi Muhammad Dalam Al-Qur'an (Aplikasi Semiotika Roland Barthes Terhadap QS 'Abasa [80]: 1).”

${ }^{18}$ Graham Allen, Roland Barthes (London: Routledge, 2003), 37.

${ }^{19}$ Barthes, Mythologies.

${ }^{20}$ Muhammad Fuad 'Abdul Baqi, Mu'jam Mufahros Li Alfadzil Qur'anil Karim (Kairo: Darul Kutub AlMishriyah, 1945), 488.

${ }^{21}$ Baqi, Mu'jam Mufahros Li Alfadzil Qur'anil Karim. 


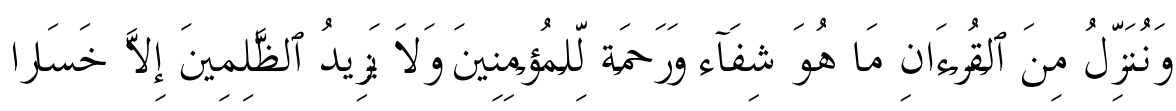

"Dan Kami turunkan dari al-Qur'an suatu yang menjadi penawar dan rahmat bagi orangorang yang beriman dan al-Qur'an itu tidaklah menambah kepada orang-orang yang zalim selain kerugian."

Syifa secara bahasa merupakan bentuk isim mashdar شفاء dari fiil madhi شفى yang memiliki arti sembuh, menyembuhkan, mengobati ${ }^{22}$. M. Quraish Shihab memberikan pandangan bahwa kata syifa memiliki arti kesembuhan atau obat, dan digunakan juga dalam pengertian keterbatasan dari kekurangan, atau ketiadaan arah dalam memperoleh manfaat. ${ }^{23}$ Dalam kitab Lisan al-Lisan diungkapkan bahwa syifa adalah obat yang dikenal/dipahami dan menyembuhkan dari rasa sakit. ${ }^{24}$ Kemudian Muhammad Idris memberikan arti kata syifa dengan kesembuhan dan sebagai obat. ${ }^{25}$

Term penyembuhan atau pengobatan dalam tatanan bahasa Arab terdapat kata selain syifa, yaitu kata dawa', thib, dan 'ilaj. Kata dawa' bermakna ke arah obat, pengobatan, dan perihal metode pengobatan. Pengertian dawa' adalah tentang persoalan badaniyah atau fisik dan memiliki relasi dengan kata thib. Thib sendiri memiliki makna umum sebagai penyembuhan dan pengobatan, pada praksisnya kata ini digunakan kepada dua bentuk penyakit yaitu terkait rohaniyah dan jasmaniyah. Kemudian kata 'ilaj memiliki padanan yang sama dengan kata thib, bermakna perihal badaniyah dan ruhaniyah, tetapi term ini lebih condong kepada persoalan nafsiyah/kejiwaan. ${ }^{26}$

Pengertian lain diberikan Husayn bin Muhammad yang dikutip Gista Siswanti dalam tulisannya bahwa Syifa didefinisikan oleh empat aspek, yaitu: kesehatan, kebahagiaan, interpretasi dan tepi. ${ }^{27}$ Kemudian Hamka memberikan pandangannya bahwa syifa adalah obatobat dan kasih sayang bagi orang yang beriman. ${ }^{28}$ Al-Qur'an adalah penawar hati terhadap penyakit kebodohan dan keraguan. Allah tidak menurunkan dari bumi dan langit sebagai penawar yang lebih umum, lebih bermanfaat, lebih besar dan lebih efektif untuk menghilangkan penyakit daripada Al-Qur'an. ${ }^{29}$

Selanjutnya, ungkapan Ibnu 'Asyur menjelaskan bahwa al-Qur'an umumnya merupakan penawar dan penyembuh berbagai penyakit, tidak hanya penyakit mental, tetapi juga penyakit fisik. Lebih lanjut menjelaskan kata min dalam ungkapan 'minal qur'ani' tidak memiliki arti sebagian, tetapi menjelaskan kandungan al-Qur'an seluruhnya adalah jenis obat. Kata syifa bermakna Musytarak artinya memiliki dua arti yaitu ada dua jenis penyembuhan yaitu penyakit

${ }^{22}$ Ahmad Warson Munawwir, Kamus Al-Munawwir (Yogyakarta: Pustaka Progressif, 1997), 731.

${ }^{23}$ M. Quraish Shihab, Tafsir Al-Mishbah: Pesan, Kesan, Dan Keserasian Al-Qur'an, IV (Tangerang: Lentera Hati, 2005), 532.

${ }^{24}$ Abu al-Fadl Jamaluddin, Lisan Al-Lisan (Beirut: Daar al-Kutub Ilmiah, n.d.), 863.

${ }^{25}$ Muhammad Idris Abdurrauf Marbawi, Kamus Idris Al-Marbawi (Bandung: Ma’arif, 1986), 323.

${ }^{26}$ Hidayah and Firdausi, 'Redefining The Meaning of Asy-Syifa' In The Qur'an As Qur'anic Healing In Pshysical Ailments."

${ }^{27}$ Siswanti, "Eksistensi Dan Konsep Syifa' Dalam Tafsir Fakhrudin Al-Razi," 2019.

${ }^{28}$ Hamka, Tafsir Al-Azhar (Singapura: Pustaka Nasional PTE LTD Singapura, n.d.), 4106.

${ }^{29}$ Ibnu Qayyim Jauziyyah, At-Tafsir Al-Qayyim (Beirut: Dar Al-Kutub Al-Ilmiyah, n.d.), 348. 
mental dan penyakit fisik. ${ }^{30}$ Syifa menampakkan arti moral yaitu, penyembuhan dan kenyamanan jiwa, dan pembebasan mereka dari keraguan, berbisik, kompleksitas dan kebingungan. ${ }^{31}$

\section{Sistem Mitologi}

Pengoperasian sistem mitologi atau tingkat kedua adalah menelusuri makna konotasi syifa yang akan menampakkan makna semiotika kedua atau disebut dengan mitos. Semiotika tingkat dua ini dapat juga dipahami sebagai pembacaan konteks sosio-historis.

Asbabun nuzul dari QS al-Isra: 82 adalah sebagaimana penjelasan Thabathaba'i yang dikutip oleh M. Quraish Shihab dalam tafsir Al-Mishbah mengatakan bahwa ayat ini berkaitan dengan deskripsi surah tentang karakteristik al-Qur'an dan fungsinya sebagai bukti kebenaran nubuwwah nabi Muhammad. Ayat ini menjelaskan fungsi al-Qur'an sebagai penawar penyakit mental. Kemudian riwayat Ibnu Mardawaih melewati para sahabat Nabi Muhammad. Ibnu Masud ra. melaporkan bahwa seseorang mendekati Nabi dan mengeluh tentang dadanya, kemudian Rasulullah bersabda: "Hendaklah dirimu membaca al-Qur'an."32

Konteks sosio-kultural dalam QS al-Isra: 82 dapat diidentifikasikan ke golongan surah Makkiyah, diturunkan setelah surah Al-Qashash. Pada fenomena sosial surah ini merupakan fase tentang persoalan sikap keras orang-orang Quraisy terhadap dakwah yang dilakukan oleh Nabi Muhammad SAW. Kegiatan dakwah Rasulullah dianggap menjadi ancaman kemaslahatan duniawi mereka (Quraisy) khususnya dalam bidang ekonomi. Peristiwa lain yang mengiringi surah ini adalah tentang perintah Allah kepada Nabi Muhammad dan umat Islam untuk menghancurkan berbagai berhala, mengenai tauhid, serta persoalan janji dan ancaman pada hari kiamat kelak. Kemudian fase ini juga merupakan kondisi situasi Nabi Muhammad hendak mempersiapkan diri hijrah ke kota Yatsrib (Madinah), karena kepungan dan tekanan yang sangat masif kepada umat Islam. ${ }^{33}$

Riwayat lain menerangkan: Abi Sa`id al-Khudry menceritakan kisah seorang sahabt yang berusaha menyembuhkan seorang kepala suku dengan membaca Surat al-Fatihah. Nabi Muhammad pernah dirawat oleh seorang pria bernama Dimad, seorang hakim sekaligus penyihir yang merawat Nabi Muhammad. Nabi Muhammad dirasuki jin, tetapi ketika Dimad bertemu Rasulullah, Nabi membaca ayat-ayat Al-Qur'an tiga kali, lalu dia berhenti untuk melanjutkannya. Kemudian dia berkata, "Saya telah mendengar banyak penyihir, dewa, dan penyair, tetapi saya belum pernah mendengar hal seperti itu." Kemudian dia berjanji untuk bersyahadat. ${ }^{34}$

Pada riwayat lain yang disampaikan dari Abu Darda bahwa Rasulullah SAW. bersabda: "Tuhan telah menurunkan baik penyakit maupun obat penawarnya. Dia menunjukkan obat penawar dari setiap penyakit. Oleh karena itu berobatlah, tetapi janganlah menggunakan meditasi yang tidak halal." Dalam hadis tersebut, Nabi sebagaimana perintah Tuhan mempersilakan agar berobat dengan cara-cara medis klasik dalam menyembuhkan penyakitnya serta dianjurkan

\footnotetext{
${ }^{30}$ Hanafi, "Qur'anic Immunity."

${ }^{31}$ Darwazah, Tafsirul Hadits: Tartibulas Suwar Hasb An-Nuzuli.

${ }^{32}$ Shihab, Tafsir Al-Mishbah: Pesan, Kesan, Dan Keserasian Al-Qur'an.

${ }^{33}$ Aksin Wijaya, Sejarah Kenabian: Dalam Perspektif Tafsir Nuzuli Muhammad Izzat Darwazah (Bandung: Mizan, 2016), 61-62.

${ }^{34}$ Fahmi Riyadi, "Resepsi Umat Atas Alquran: Membaca Pemikiran Navid Kermani Tentang Teori Resepsi Alquran," HUNAFA: Jurnal Studia Islamika 11, no. 1 (2014): 50, https://doi.org/10.24239/jsi.v11i1.339.43-60.
} 
memanfaatkan alat-alat modern demi kesembuhannya. Namun, Rasulullah memberi peringatan agar tidak menggunakan mantra-mantra sihir yang diharamkan, dosa, dan penuh dengan takhayul. ${ }^{35}$

Pada zaman Nabi Muhammad juga telah terjadi praktik pengobatan dengan berbagai cara. Data ini penulis ambil dari kitab Zaadul Ma'ad dan kitab lainnya yang membahas tentang tema tersebut. Nabi Muhammad saw, pernah memberikan keringanan melakukan ruqyah terhadap pengaruh mata ('ain), panas, dan gigitan semut. Sebagaimana hadis Nabi:

Diriwayatkan oleh Malik dari Ibn Syihab, dari Abi Umamah bin Sahl bin Hanif, ia berkata: "Amir bin Rabiah melihat Sahl sedang mandi, kemudian ia berkata, 'Demi Allah, aku tidak pernah melihat pemandangan seperti sekarang, tiada kulit yang disembunyikan.' Sahl kemudian memakai kain, dan Amir mendatangi Rasulullah, kemudian menceritakan hal tersebut. Lalu Beliau nampak marah kepadanya dan bersabda, "atas dasar apa salah seorang kalian membunuh saudaranya? Tidakkah kamu memberkatinya? Mandilah untuknya.'. Kemudian Amir membasuh mukanya dan kedua tangan, kedua siku, dan kedua lututnya serta ujung-ujung kakinya dan bagian dalamnya di letakkan dalam baskom, lalu menuangkannya kepada Sahl, setelah itu Sahl pun membaur bersama orang lain (sembuh) setelah sebelumnya sakit akibat mata Amir bin Rabiah yang memujinya". ${ }^{36}$

Dengan menggunakan analisis Roland Barthes yang menyingkap tabir ideologi di balik sebuah pemahaman, maka penulis menelusuri pemahaman tentang pengobatan yang Rasulullah tawarkan berupa doa dan zikir, walaupun ada juga beberapa yang berupa makanan dan minuman serta tips-tips hidup sehat. Doa dan zikir memiliki 15 kandungan obat (syifa). Apabila dengan doa dan zikir tidak cukup kuat untuk menghilangkan kesusahan pada diri seorang hamba, maka sesungguhnya terdapat kondisi hati yang salah dan berpenyakit. Adapun kandungan obat yang terdapat dalam doa dan zikir, yaitu ${ }^{37}$ :

1. Tauhid Rububiyyah (pengakuan bahwa Allah merupakan satu-satuNya pemelihara alam semesta)

2. Tauhid Uluhiyyah (pengakuan bahwa Allah satu-satuNya yang berhak dan wajib disembah)

3. Tauhid 'Ilmi (pengakuan bahwa Allah satu-satuNya yang Maha Mengetahui)

4. Mensucikan Allah dari angaapan bahwa Dia menzhalimi hamba-Nya.

5. Pengakuan seorang hamba bahwa dialah yang Halim.

6. Bertawassul.

7. Memohon pertolongan hanya kepada-Nya.

8. Pengakuan hamba untuk menaruh harapan kepada-Nya.

9. Mewujudkan sikap bertawakkal bahwa Allah lah yang mampu mengobatinya.

10. Hendaklah ia menggiring hatinya ke dalam lautan suci ayat-ayat al-Qur'an dan menjadikan al-Qur'an bagaikan musim semi bagi binatang.

${ }^{35}$ Afzalur Rahman, Ensiklopediana Ilmu Dalam Al-Qur'an, II (Bandung: Mizania, 2007), 372.

${ }^{36}$ Ibnu Qayyim Jauziyyah, Mukhtashar Zaadul Ma'ad: Bekal Hidup Muslim, trans. Marsuni Sasaky (Jakarta: AKBAR, 2008), 295-96.

${ }^{37}$ Jauziyyah, Mukhtashar Zaadul Ma'ad: Bekal Hidup Muslim. 
11. Beristighfar.

12. Bertaubat.

13. Melaksanakan shalat.

14. Mengakui tidak memiliki daya dan upaya, serta menyerahkannya kepada Allah.

Syifa yang diungkapkan dalam al-Qur'an mengandung pengertian pengobatan medis sekaligus pengobatan spiritual melalui doa, yaitu pembacaan ayat-ayat al-Qur'an dan zikir dengan ungkapan-ungkapan thayyibah: La ilaha illallah (لاإله إلااله ), Allahumma shalli 'ala sayyidina Muhammad (أللهم صل على سيدنا محمد), doa dengan asmaul husna: Ya Bari'u, Ya Qawiyyu, Ya Matinu, Ya Hayyu, Ya Qayyumu) يا بارئ- يا قوي يا متين- يا حي يا قيوم), dan sebagainya. Konsep syifa yang dikemukakan oleh Ibnu Qayyim yaitu persoalan hidup yaitu penyembuhan kejiwaan dari gangguan-gangguan psikis. Dalam penafsirannya, ia banyak menguraikan penyembuhan penyakit dengan al-Qur'an dan sunnah serta mengaplikasikannya sebagai dalil dalam mengemukakan metode penyembuhan berbagai penyakit kejiwaan serta disebutkan faktor-faktor yang menyebabkan timbulnya penyakit. ${ }^{38}$

Berdasarkan kepada pemaparan di atas, dapat dipahami makna secara implisit yang dimunculkan pada QS al-Isra: 82 adalah memahami Al-Qur'an sebagai the healing book sebagaimana ungkapan dari Abduldaem Al-Kaheel. ${ }^{39}$ Ideologi pola hidup sehat dengan al-Qur'an menjadi persoalan praktik masyarakat menggapai kesehatan jasmani dan rohani, kedokteran juga merupakan makna mitos penyembuhan dengan menggunakan al-Qur'an. Pada realitasnya terdapat orang-orang yang mempercayainya tanpa ada penelitian lebih lanjut atau dikenal sebagai mengikuti lewat iman. Selain itu, beberapa lainnya masih perlu melakukan eksperimen atau penelitian tentang ilmu kedokteran atau praktik kesembuhan menggunakan al-Qur'an.

\footnotetext{
38 Jauziyyah.

${ }^{39}$ Kaheel, Al-Qur'an The Healing Book.
} 


\section{Kesimpulan}

Linguistik $\left\{\begin{array}{|l|l|}\begin{array}{l}\text { 1. Signifier (Penanda I) } \\ \text { Syifa (Penyembuhan atau } \\ \text { pengobatan) }\end{array} & \begin{array}{l}\text { 2. Signified (Petanda I) } \\ \text { Pengobatan dengan al-Qur'an }\end{array} \\ \begin{array}{l}\text { 3. Sign (Tanda I) } \\ \text { a. Penanda II } \\ \begin{array}{l}\text { Syifa adalah praktik } \\ \text { pengobatan dengan } \\ \text { menggunakan al-Qur'an }\end{array}\end{array} & \begin{array}{l}\text { b. Petanda II } \\ \text { Pengobatan dan penyembuhan } \\ \text { dengan al-Qur'an baik psikis } \\ \text { maupun fisik }\end{array} \\ \begin{array}{l}\text { Pengobatan dengan menggunakan mediasi al-Qur'an memiliki } \\ \text { orientasi objek rohani dan jasmani. Persoalan pola hidup sehat ala } \\ \text { Nabi Muhammad menjadi referensi utama. Baik diperhatikan dari } \\ \text { segi makananna, maupun tingkah laku dan tutur kata. }\end{array} \\ \hline\end{array}\right.$

Bagan 2. Analisis Semiotika ala Barthes atas kata syifa dalam al-Qur'an

Pada rangkaian penjelasan yang telah diuraikan tentang makna syifa dalam QS al-Isra: 82, dapat dipahami, sebagaimana tergambar dalam Bagan 2, bahwa semiotika tahap pertama kajian linguistik kata syifa memberikan makna bukan hanya pengobatan ruhani, tapi juga pikis. Kemudian sistem mitologi atau mitos memunculkan makna konotasi yaitu syifa bukan saja berorientasi kepada psikis saja, melainkan kepada penyembuhan keduanya yakni psikis dan fisik seseorang menggunakan mediasi al-Qur'an, dengan menggunakan metode ala Nabi Muhammad. Setelah itu, pesan yang terkandung dalam ayat tersebut adalah dianjurkan melakukan pengobatan dengan menggunakan al-Qur'an, dengan praktik-praktik yang halal dan tidak dibolehkan melakukan praktik pengobatan yang dapat menggolongkan kepada kesyirikan seperti mantramantra sihir dukun, mediasi kepercayaan benda, dan hal lainnya yang bersifat takhayul.

\section{Referensi}

Allen, Graham. Roland Barthes. London: Routledge, 2003.

Baqi, Muhammad Fuad 'Abdul. Mu'jam Mufahros Li Alfadzil Qur'anil Karim. Kairo: Darul Kutub Al-Mishriyah, 1945.

Barthes, Roland. Mythologies. New York: The Noonday Press, 1991.

Darwazah, Muhammad Izzat. Tafsirul Hadits: Tartibulas Suwar Hasb An-Nuzuli. II. Beirut: Darul Ghorbi Al-Islami, 2000.

Duncan, James S, and Duncan G Nancy. "Ideology and Bliss: Roland Barthes and The Secret Histories of Landscape." In Postmodernism: Critical Concepts, edited by Victor E. Taylor and Charles E. Winquist. London: Routledge, 1998.

Fahrudin, Fahrudin. "Tanah Sebagai Bahan Penciptaan Manusia: Analisis Semiologi Roland 
Barthes Pada Kata Thin Dalam Al-Qur'an.” TAFSE: Journal of Qur'anic Studies 6, no. 1 (2021): 21. https://doi.org/10.22373/tafse.v6i1.8036.

Fatah, Abdul. "Analisis Semiotika Roland Barthes Tentang Ashabul Fil." AL-TADABBUR 5, no. 2 (2020): 233-48.

Hamka. Tafsir Al-Azhar. Singapura: Pustaka Nasional PTE LTD Singapura, n.d.

Hanafi, Muchlish M. “Qur'anic Immunity.” In Webinar Prospek Dan Tantangan Al-Qur'an Sebagai Obat Di Masa Pandemi. Salatiga: IAIN Salatiga, 2020.

Hidayah, Aida, and Fitriana Firdausi. 'Redefining The Meaning of Asy-Syifa' In The Qur'an As Qur'anic Healing In Pshysical Ailments." Jurnal Studi Ilmu-Ilmu Al-Qur'an Dan Hadis 22, no. 1 (2021): 255. https://doi.org/10.14421/qh.2021.2201-12.

Ibrahim, Mohamed Akhiruddin, M Shahir Mohd Shah, and Rabiatul Adawiyah Mohd. "Concept of Shifa in Al-Quran: Quranic Medicine Approach in Healing Physical Ailment." Al-Qanatir International Journal of Islamic Studies. 1, no. 2 (2015): 1-19.

Ismujihastuti, RAGD, and Adi Bayu Mahadian. "Representasi Wanita Dalam Sampul Album Raisa (Analisis Semiotik Roland Barthes Terhadap Sampul Album Raisa Andriana 'Raisa' Dan 'Heart to Heart')." EProceedings of Management, 2015. https://openlibrarypublications.telkomuniversity.ac.id/index.php/management/article/view/3 444.

Jamaluddin, Abu al-Fadl. Lisan Al-Lisan. Beirut: Daar al-Kutub Ilmiah, n.d.

Jauziyyah, Ibnu Qayyim. At-Tafsir Al-Qayyim. Beirut: Dar Al-Kutub Al-Ilmiyah, n.d.

. Mukhtashar Zaadul Ma'ad: Bekal Hidup Muslim. Translated by Marsuni Sasaky. Jakarta: AKBAR, 2008.

Kaheel, Abduldaem. Al-Qur'an The Healing Book. II. Jakarta: Tarbawi Press, 2011.

Khitmatiar, Azkiya. "Konsep Poligami Dalam Al-Qur'an (Aplikasi Semiologi Roland Barthes).” QOF 3, no. 1 (2019): 54-66. https://doi.org/10.30762/qof.v3i1.903.

Kusuma, Putu Krisdiana Nara, and Iis Kurnia Nurhayati. “Analisis Semiotika Barthes Pada Ritual Otonan Di Bali." Jurnal Manajemen Komunikasi 1, no. 2 (2019): 195. https://doi.org/10.24198/jmk.v1i2.10519.

Latif, Umar. "Al-Qur'an Sebagai Sumber Rahmat Dan Obat Penawar (Syifa') Bagi Manusia." Jurnal Al-Bayan 21, no. 30 (2014): 88. https://doi.org/10.22373/albayan.v20i30.125.

Lestari, Cucun Fuji. "Penafsiran Ayat-Ayat Syifa Dalam Al-Qur'an (Studi Komparatif Tafsir AlJailâni Dan Al-Assâs).” Institut Ilmu Al-Qur’an Jakarta, 2019.

Marbawi, Muhammad Idris Abdurrauf. Kamus Idris Al-Marbawi. Bandung: Ma’arif, 1986.

Munawwir, Ahmad Warson. Kamus Al-Munawwir. Yogyakarta: Pustaka Progressif, 1997.

Pradopo, Rachmat Djoko. "Semiotika: Teori, Metode, Dan Penerapannya Dalam Pemaknaan Sastra." Jurnal Humaniora 11, no. 1 (1999): 76-84. https://doi.org/10.22146/jh.628.

Rahman, Afzalur. Ensiklopediana Ilmu Dalam Al-Qur'an. II. Bandung: Mizania, 2007.

Riyadi, Fahmi. "Resepsi Umat Atas Alquran: Membaca Pemikiran Navid Kermani Tentang Teori Resepsi Alquran." HUNAFA: Jurnal Studia Islamika 11, no. 1 (2014): 43. https://doi.org/10.24239/jsi.v11i1.339.43-60.

Shihab, M. Quraish. Tafsir Al-Mishbah: Pesan, Kesan, Dan Keserasian Al-Qur'an. IV. Tangerang: Lentera Hati, 2005. 
Shiwani, Muhammad Hanif. "A Thematic Analysis of Human Nutrition as Described in the Holy Qur' an.” Journal of The British Islamic Medical Association 6, no. 2 (2020): 1-14.

Siswanti, Gista Naruliya. "Eksistensi Dan Konsep Syifa' Dalam Tafsir Fakhrudin Al-Razi." AlMada: Jurnal Agama, Sosial, Dan Budaya 2, no. 2 (2019): 1-16. https://doi.org/10.31538/almada.v2i2.330.

"Eksistensi Dan Konsep Syifa' Dalam Tafsir Fakhrudin Al-Razi." Al-Mada: Jurnal Agama, Sosial, Dan Budaya 2, no. 2 (2019): 1-16. https://doi.org/10.31538/almada.v2i2.330.

Sofyan, Ahmad. "Konsep Syifa Perspektif Tafsir Sya'rowi." Institut Perguruan Tinggi Ilmu AlQur'an Jakarta, 2016.

Umaroh, Dewi. "MAKNA 'ABASA NABI MUHAMMAD DALAM AL-QUR'AN (APLIKASI SEMIOTIKA ROLAND BARTHES TERHADAP Q.S 'ABASA[80]: 1)." Al-Bayan: Jurnal Studi Ilmu Al- Qur'an Dan Tafsir 5, no. 2 (2020): 116-27. https://doi.org/10.15575/albayan.v5i2.11640.

Wijaya, Aksin. Sejarah Kenabian: Dalam Perspektif Tafsir Nuzuli Muhammad Izzat Darwazah. Bandung: Mizan, 2016. 